ционной культуры обучающихся в системе непрерывного образования: автореферат дис. ... доктора педагогических наук: 13.00 .08 / Овчинникова Ираида Григорьевна. Магнитогорск, 2009. 45 с.

8. Оленев С. М. Информационная культура на рубеже тысячелетий: преемственность и новации / С. М. Оленев // Информационная культура личности: прошлое, настоящее, будущее. - Краснодар, 1996. С. 52-53

\section{REFERENCES}

1. Atayan, A. M. (2001). Didakticheskie osnovyi formirovaniya informatsionnoy kulturyi lichnosti $v$ usloviyah informatizatsii obschestva. [Didactic fundamentals of the person information culture formation in the conditions of society informatization]. Vladikavkaz.

2. Galeta, Ya. V. (2007). Deyaki aspekti vivchennya problemi formuvannya informacijnoyi kulturi majbutnogo vchitelya. [Some aspects of study of the problem of future teacher's information culture formation]. Ternopil.

3. Galeta, Ya. V. (2011). Informacijna kultura v profesijnij pidgotovci majbutnogo pedagoga. [Information culture in the professional training of the future teacher]. Kiyiv.

4. Geyn, A. G. Metodika prepodavaniya sovremennogo kursa informatiki. [Teaching methodology for a modern computer science course]. Moskva.

5. Makarova, N. V., Volkov, V. B. (2011). Informatika: uchebnik dlya studentov vyisshih uchebnyih zavedeniy, obuchayuschihsya po napravleniyam podgotovki bakalavrov «Sistemnyiy analiz $i$ upravlenie» $i$ "Ekonomika $i$ upravleni». [Computer science: a textbook for university students

УДК 37.091.12:005.962.131:78

DOI: 10.36550/2415-7988-2020-1-186-233-237 enrolled in the bachelor degree program «System analysis and management» and «Economics and Management»]. Moskva.

6. Ovchinnikova, K. P. (1998). Informatsionnokompyuternaya kultura $v$ kontekste gotovnosti lichnosti $k$ samoobrazovaniyu. [Information and computer culture in the context of a individual readiness for self-education]. Chelyabinsk.

7. Ovchinnikova, I. G. (2009). Razvitie informatsionnoy kulturyi obuchayuschihsya $v$ sisteme nepreryivnogo obrazovaniya. [The development of the students' information culture in continuous education system]. Magnitogorsk.

8. Olenev, S. M. (1996). Informatsionnaya kultura na rubezhe tyisyacheletiy: preemstvennost $i$ novatsii. [Millennium information culture: continuity and innovation]. Krasnodar.

\section{ВІДОМОСТІ ПРО АВТОРА}

ШТОМПЕЛЬ Ганна Владиславівна викладач кафедри іноземних мов Центральноукраїнського національного технічного університету.

Наукові інтереси: феномен «інформаційна культура»; проблема становлення особистості в умовах інформатизації суспільства.

\section{INFORMATION ABOUT THE AUTHOR}

SHTOMPEL Hanna Vladyslavivna - lecturer at The Department of foreign languages Central Ukrainian National Technical University.

Circle of research interests: the phenomenon of «information culture»; problem of personality formation in the conditions of informatization of society.

Стаття надійшла до редакиії 14.01.2020 p.

МИХАСБКОВА Марина Анатоліївна кандидат педагогічних наук, доцент, завідувач кафедри теорії та методики музичного мистецтва Хмельницької гуманітарно-педагогічної академії ORCID: http://orcid.org/0000-0003-1248-3903 e-mail: chudo43@gmail.com

\title{
ЕКСПЕРИМЕНТАЛЬНА ПЕРЕВІРКА ЕФЕКТИВНОСТІ СИСТЕМИ ФОРМУВАННЯ ДОСВІДУ МУЗИЧНО-ПЕДАГОГІЧНОЇ ДІЯЛЬНОСТІ МАЙБУТНІХ УЧИТЕЛІВ МУЗИЧНОГО МИСТЕЦТВА
}

Постановка та обгрунтування актуальності проблеми. На сучасному етапі розвитку професійної музичної освіти України необхідно створити систему освітньої роботи на факультетах мистецтв та музично-педагогічних факультетах, яка б успішно долала проблеми i протиріччя, уникала застарілих форм, засобів і методів навчально-виховного процесу в фаховій підготовці майбутніх учителів музичного мистецтва. Досягнути бажаного результату, на нашу думку, можна лише із застосуванням 
системного підходу та моделювання фахової діяльності.

Аналіз останніх досліджень і публікацій. Основи системного підходу в педагогічній підготовці вивчали О. Дудник, В. Желанова, Я. Зорій, Н. Кузьміна, М. Маєрович, Н. Сидорчук, Л. Шрагіна та інші. Розкривали змістове наповнення системи музично-педагогічної підготовки вчені А. Козир, Л. Масол, О. Михайличенко, Г. Падалка, О. Ростовський, О. Рудницька, В. Черкасов та інші. Однак дослідження цих та інших учених не спрямовані на формування технології оцінювання ефективності системи організації фахової підготовки вчителів музичного мистецтва, зокрема досвіду музичнопедагогічної діяльності.

Мета статті. Метою статті $є$ розкриття етапів та методики експериментальної перевірки сформованості системи досвіду музично-педагогічної діяльності майбутніх педагогів-музикантів.

Виклад основного матеріалу дослідження. Актуальність розробки нової системи професійної підготовки вчителів музичного мистецтва виникла у зв'язку із використанням предметно-інтегративної системи, яку запропонувала для мистецької освіти школярів Л. Масол [3]. Автор концепції інтегрованого курсу «Мистецтво» вважає ऑii оптимальною, оскільки така педагогічна модель була покладена в основу державних освітніх стандартів у галузі «Мистецтво» [4, с. 36]. Зауважимо, що ідея втілюється у практику викладання в загальноосвітніх школах вже багато років, але досі лишається відкритим питання професійної підготовки спеціалістів, які би забезпечували викладання предмета «Мистецтво» на належному рівні. Такий предмет у початковій i середній школі $\epsilon$, проте навчальні заклади поки ще не готують фахівців, які відповідають змісту підготовки. Проблема виникає у зв'язку з відсутністю у Національному класифікаторі України i Національній рамці кваліфікацій назви такої спеціальності. Тому факультети мистецтв продовжують готувати окремо вчителів образотворчого та вчителів музичного мистецтва. Натомість директори загальноосвітніх шкіл проблему кадрової нестачі долають, поділяючи цей курс по одній годині на образотворче i музичне мистецтво відповідно, тим самим забезпечуючи навантаженням фахівців. Але проблема не зникає, оскільки майбутні педагогимузиканти i вчителі образотворчого мистецтва вивчають методику викладання фахових дисциплін, а не курсу «Мистецтво», який має свої особливості.

У зв'язку з цим актуальним залишаються питання шляхів адаптації навчальних планів, відповідно до вимог шкільної програми, із невеликою корекцією робочих програм, до яких викладачі вищих навчальних закладів включають теми висвітлення інтегрованого курсу. Тому запропонована система формування досвіду музично-педагогічної діяльності майбутнього вчителя музичного мистецтва цілком враховує нововведення та зміни, які останнім часом відбуваються в системі музичної освіти України. Тобто, вона містить ознаки системно-синергетичного підходу, зокрема відкритість (інноваційність), взаємодію (колективну дію), самоорганізацію (здатність діяти в умовах змінної інформації). Але досвід діяльності не передбачає досягнення повної свободи студентів, а включає контроль i корекцію педагога в освітньому процесі.

Система досвіду музично-педагогічної діяльності майбутнього вчителя музичного мистецтва має свою структуру (будову), розташування елементів у системі. Вона включає методологічний, теоретичний, технологічний та діагностичний рівень та етапи (концептуальний, алгоритмічнопроцесуальний, евристичний, творчорезультативний), а також зв'язки прямого i зворотного плану між ними.

На початковому теоретичному етапі студенти, відвідуючи предмети навчального плану, отримують алгоритм дій і операції, вивчаючи їх відповідно до фаху, оволодівають предметними методами i прийомами, моделюють особисту діяльність відповідно до висунутих норм і на основі отриманих результатів проводять корекцію своєї поведінки. Наступним щаблем є перехід на більш вищий практичний (технологічний) рівень діяльності, на якому майбутні фахівці вчаться взаємодіяти із учасниками музичнопедагогічного процесу, моделюють діяльність у відповідності із отриманими знаннями i, отримуючи результати, корегують свою роботу та інструментарій (прийоми, вправи, вчинки тощо). Останнім етапом (діагностичний рівень) $є$ узагальнення практичного досвіду i проведення певних музично-педагогічних досліджень, практикумів із метою прогнозування результатів та досягнення майстерності фахівця [2, с. 43].

Організовуючи експериментальну перевірку, ми брали за основу такі концептуальні iдё̈:

- досвід музично-педагогічної діяльності учителя музичного мистецтва реалізується в 
інтегративності (міжпредметній та міжгалузевій);

- у системі музично-педагогічної освіти формування досвіду музично-педагогічної діяльності має відбуватися комплексно (багатокомпонентно) та цілеспрямовано під керівництвом педагога;

- національна визначеність процесу має стати основним вектором побудови навчального матеріалу;

- процес формування досвіду музичнопедагогічної діяльності має відбуватися системно і бути спрямований на розвиток усіх компонентів досліджуваного феномену, що регулюють практичні сторони навчальновиховного процесу.

У відповідності до мети дослідноекспериментальної роботи, ми сформулювали такі їі завдання:

- систематизувати та структурувати процес професійної діяльності у закладах вищої освіти відповідно до моделі сформованості досвіду музично-педагогічної діяльності;

- обгрунтувати та описати систему досвіду музично-педагогічної діяльності необхідну майбутньому учителю музичного мистецтва;

- апробувати методику формування досвіду музично-педагогічної діяльності майбутніх учителів музичного мистецтва;

- запропонувати методичні рекомендації щодо формування досвіду музичнопедагогічної діяльності майбутніх учителів музичного мистецтва у практиці викладання вищих навчальних закладів.

Аналіз навчальних планів та навчальних програм першого (бакалаврського) рівня вищої освіти дозволив встановити, якою мірою зміст та структура професійної підготовки відображають специфіку фахової діяльності, відповідають педагогічній спрямованості та сприяють формуванню досвіду музично-педагогічної діяльності майбутніх учителів музичного мистецтва. На основі чого ми виділили три етапи роботи:

Перший етап передбачав професійну орієнтацію та адаптацію до навчання, формування базових знань і умінь. На цьому етапі студенти засвоюють дії i операції відповідного фаху на рівні теоретичних узагальнень, вибору музично-педагогічних засобів, оволодівають методами і прийомами. У результаті відбувається усвідомлення суті фаху, моделювання професійних дій за алгоритмом, здійснюється корекція музичнопедагогічної діяльності. Музично-теоретична підготовка та освоєння практичних умінь і навичок (технології виконання музичних творів, методико-технологічних знань) реалізується на основі розвинутих емоцій та свідомих мотивів.

На другому етапі (2-3 курс) відбувається поглиблене вивчення предметів фахового спрямування, результативне оволодіння системою дій, операцій, прийомів тощо. Цей етап характеризується переходом на більш свідомий рівень практичної діяльності, ऑiі моделювання, залучення усіх форм взаємодії у знайомих ситуаціях та за зразком. У результаті студент удосконалює інструментарій професійної підготовки за допомогою традиційних та інноваційних методик. Цей етап включав формування комунікативних навичок професійної діяльності та набуття організаційнопрогностичного досвіду.

Третій етап (4 курс) передбачав інтегрування і генералізацію знань, умінь і як результат - оволодіння практичним досвідом. Останній етап виводив майбутнього вчителя музичного мистецтва на рефлексивний рівень осягнення професії, коли відбувається прогнозування результатів роботи в нових ситуаціях, освоєння іï основних творчих принципів та узагальнення на вищому інтегративному рівні теоретичних i практичних положень діяльності.

Аналіз проблем формування досвіду музично-педагогічної діяльності студентів музично-педагогічних факультетів підвів нас до ідеї застосування комплексних шляхів інтегрування в практику викладання закладів вищої школи, коли зміст фахової підготовки, реалізуючись у конкретних навчальних циклах і зберігаючи специфіку викладання, об'єднується навколо дисциплін-комплексів, суміжних предметів, тем-комплексів.

Робота була зорієнтована на використання науково-методологічних підходів до професійної підготовки майбутніх учителів музичного мистецтва (системний, діяльнісний, культурологічний, особистісний, компетентнісний та синергетичний); відокремлення концептуальних ідей (інтегративності, комплексності, національної визначеності, системності) i спрямування ними особистісного змісту у навчанні; визначення умов та принципів діяльності педагогів-музикантів, які приведуть до якісно нового рівня музично-педагогічної освіти; програмування та накопичення фактологічного матеріалу під час засвоєння алгоритмічний дій i операцій у фаховій діяльності (функції, компетентності, форми, методи, засоби, шляхи).

У процесі роботи зі студентами спеціальності 014 Середня освіта (Музичне 
мистецтво) впроваджувалися нові підходи, шляхи діяльності, використовувались інноваційні та традиційні методи, впроваджувався спецкурс «Мистецький практикум». Апробована система формування досвіду музично-педагогічної діяльності була доповнена метою, змістом, формами i методами, пакетом методичних рекомендацій, спецкурсом «Мистецький практикум» i завданнями до нього. Структурування змісту спецкурсу «Мистецький практикум» передбачало системний виклад матеріалу відповідно до нових міждисциплінарних зв'язків, ознайомлення зі змістом, метою і завданнями мистецької освіти.

До завдань спецкурсу ми віднесли: сприяти професійному зростанню бакалаврів; розкривати творчий потенціал педагога, який спроможний інтегрувати різноманітні методичні та практичні матеріали 3 різних видів мистецтв; ознайомлювати майбутніх викладачів мистецьких дисциплін із альтернативними програмами викладання; засвоювати методологічні і методичні основи планування, організації та проведення мистецьких уроків; застосовувати різні форми, методи та прийоми викладання мистецьких дисциплін; навчитися спілкуватися та взаємодіяти на мистецьких заняттях. У результаті ознайомлення 3 навчальними темами спецкурсу «Мистецьких практикум» майбутні учителі музичного мистецтва усвідомлювали себе суб'єктом педагогічної діяльності, отримували певний досвід комплексної діяльності, осягали необхідність системної організації діяльності педагогів-музикантів.

Лекційні заняття спецкурсу «Мистецький практикум» охоплювали теоретичні основи інтеграції мистецької освіти. Засвоєння тем відбувалося на лекціяхбесідах, лекціях-дискусіях, лекціях із застосуванням елементів «мозкового штурму», лекціях із аналізом музичнопедагогічних або мистецтвознавчих ситуацій, програмованих лекціях-консультаціях [1, c. 349]. Практичні заняття допомагали студентам усвідомлювати використання професійних умінь в інтегративній мистецькій діяльності. Вони проводилися у формі тренінгів, кейс-вправ, ділових (рольових) ігор, «мозкового штурму», проектів, виконання дослідницьких робіт і дозволили студентам спробувати свої сили в ситуаціях, наближених до реальності, виявити недоліки професійної підготовки і варіанти їх вирішення.

Самостійна робота студентів передбачала такі методи роботи, як читання 3 аркуша нового авторського твору; домашню самостійну роботу над музичним твором; індивідуальну інтерпретацію музичного твору, виконання його окремих фрагментів тощо. У рамках реалізації спецкурсу було продумано силабус дисципліни, який розкривав методи навчання та контролю; орієнтовне оцінювання видів навчальної діяльності студентів за рейтинговою системою; розподіл балів, які отримують студенти в процесі засвоєння спецкурсу «Мистецький практикум»; шкалу оцінювання за національна та ECTS системою; методичне забезпечення спецкурсу; рекомендовану літературу; інформаційні ресурси дисципліни.

Висновки та перспективи подальших розвідок напряму. Отже, результативність навчальної діяльності в процесі експериментальної перевірки виражалася у розвитку здатності до комплексного осягнення мистецьких явищ; уявленнях щодо відокремлення у навчальній діяльності синтетичних понять та термінів; у засвоєнні теоретичних та практичних основ методики викладання мистецьких дисциплін; у здатності студентів комплексно розуміти (сприймати, оцінювати, осмислювати) мистецькі твори; у розвитку мистецької рефлексії, художньої та музичної пам'яті, мислення особистості педагога-музиканта; у сформованих уміннях музично-педагогічної діяльності; у активізації спілкування на основі спільної взаємодії з дітьми на уроках мистецтва; у спроможності майбутніх учителів музичного мистецтва використовувати отриманий досвід на практиці. Подальшого дослідження потребує питання впровадження дієвих механізмів корекції дій, операцій та вчинків у процесі музичнопедагогічного навчання, які забезпечать у майбутньому розвиток педагогічної майстерності (виконавської, лекторської, педагогічної) й стануть основою передового музично-педагогічного досвіду.

\section{СПИСОК ДЖЕРЕЛ}

1. Зорій Я. Б. Теоретичні і методичні засади підготовки майбутніх офіцерів запасу в закладах вищої освіти: дис. ... доктора пед. наук: 13.00.04 / Зорій Ярослав Богданович. - Хмельницький, 2018. $406 \mathrm{c}$.

2. Кухарев Н. В., Решетько В. С. Диагностика педагогического мастерства и педагогического творчества (опыт, критерии, измерения, прогнозирование) / Н. В. Кухарев, В. С. Решетько. - Ч.ІІ. - Минск: Адукацыя и выхавание, 1996. 95 с.

3. Масол Л. М. Методика навчання мистецтва у початковій школі: Посібник для вчителів / Л. М. Масол, О. В. Гайдамака, Е. В. Бєлкіна, О. В. Калініченко, І. В. Руденко. - Х. : Веста: Видавництво «Ранок», 2006. 256 с. 
4. Масол Л. М. Методика навчання інтегрованого курсу «Мистецтво». [Електронний pecypc]. - - Режим доступу: https://www.geneza.ua/sites/default/files/productimages/Metodyky/Masol_Mystetstvo_Metodyka.pdf (дата звернення 4.01.2020)

\section{REFERENCES}

1. Zorij, Ja. B. (2018). Teoretychni i metodychni zasady pidghotovky majbutnikh oficeriv zapasu $v$ zakladakh vyshhoji osvity. [Theoretical and Methodological Principles of the Training of the Future Reserve Officers in Higher Education Institutions] Khmeljnycjkyj.

2. Kukharev, N. V., Reshetjko, V. S. (1996). Dyaghnostyka pedaghoghycheskogho masterstva y pedaghoghycheskogho tvorchestva (opy't, kryteryy, yzmerenyja, proghnozyrovanye. [Diagnostics of Pedagogical Skill and Pedagogical Creativity (Experience, Criteria, Measurements, Forecasting)]. Mynsk.

3. Masol, L. M. (2006). Metodyka navchannja mystectva $u$ pochatkovij shkoli: Posibnyk dlja vchyteliv. [Methods of Teaching Art in Primary School]. Kharkiv.
4. Masol, L. M. (2019). Metodyka navchannja integhrovanogho kursu «Mystectvo». [Methods of Teaching Integrated Course «Art»]

\section{ВІДОМОСТІ ПРО АВТОРА}

МИХАСЬКОВА Марина Анатоліївна кандидат педагогічних наук, доцент, завідувач кафедри теорії та методики музичного мистецтва Хмельницької гуманітарно-педагогічної академії.

Наукові інтереси: професійна підготовка майбутнього вчителя музики, формування фахової компетентності музикантів-педагогів, досвід музично-педагогічної діяльності.

INFORMATION ABOUT THE AUTHOR

MYKHASKOVA Maryna Anatoliivna Candidate of Pedagogical Sciences, Assistant Professor, Head of the Department of Theory and Methods of Music art of Khmelnytskyi HumanitarianPedagogical Academy.

Circle of scientific interests: professional preparation of the future music teacher, formation of professional competence of musicians-pedagogues, experience of music-pedagogical activity.

Стаття надійшла до редакиії 12.01.2020 p. 